\title{
ASSESSMENT OF HEMATOLOGICAL INDICES AMONG WORKERS IN SILVER JEWELRY UNITS
}

\author{
SHALINI KV*, AYYAPPA DAS MP \\ Department of Biotechnology, Rathinavel Subramaniam College of Arts and Science, Coimbatore - 641 402, Tamil Nadu, India. \\ Email: shaliniks@rvsgroup.com
}

Received: 09 May 2017, Revised and Accepted: 23 May 2017

ABSTRACT

Objective: Workers in the silver jewelry manufacturing units are exposed to heavy metals and toxic compounds during manufacturing. Hence, the present study aimed to assess the hematological indices among the workers in silver jewelry manufacturing units.

Methods: A cross-sectional study was conducted in various silver jewelry manufacturing units located in Coimbatore, Tamil Nadu. One hundred and forty eight exposed and 35 unexposed (control) participants were included in this study. Their hematological indices were assessed.

Results: There was significant $(\mathrm{p}<0.05)$ increase of serum silver $(\mathrm{Ag})$ and hematological profile such as red blood cell $(\mathrm{RBC})$, hematocrit, and the hemoglobin levels of exposure groups (B, C, D, and E) were found to be significantly decreased ( $<<0.05)$ compared to control group (A). There was also significant increase $(\mathrm{p}<0.05)$ in differential count and mean corpuscular hemoglobin $(\mathrm{MCH})$, mean corpuscular hemoglobin concentration $(\mathrm{MCHC})$, platelet (PLT), platelet distribution width (PDW), and mean platelet volume (MPV) levels in exposed groups (B, C, D, and E) than controls (A).

Conclusion: Decrease in RBC indices and the increased differential count of MCH, MCHC, PLT, PDW, and MPV levels might be due to the exposure to $\mathrm{Ag}$ in the jewelry units. In view of these results, it appears that ionized Ag induces hematological disturbances and the present study clearly establish that there were minimal negative effects of Ag exposure on hematological indices.

Keywords: Silver, Jewelry units, Hematological indices.

(C) 2017 The Authors. Published by Innovare Academic Sciences Pvt Ltd. This is an open access article under the CC BY license (http://creativecommons. org/licenses/by/4. 0/) DOI: http://dx.doi.org/10.22159/ajpcr.2017.v10i9.19809

\section{INTRODUCTION}

Silver (Ag) occurs naturally in its pure form. It has been valued as a precious metal used to make ornaments, tablewares, utensils, and currency coins $[1,2]$. It is also used industrially in electrical conductors, mirrors, and catalysis of chemical reactions. Its compounds are used in photographic film and are also used as dental alloys, disinfectants, and microbicides [3]. It has been known that Ag-based compounds are useful in a wide range of bactericidal applications [4-6]. Important sources of atmospheric Ag from human activities include steel refining, fossil-fuel combustion, cement manufactures, processing of ores, cloud seeding, and municipal waste incineration.

Recent studies confirm that Ag in its metallic state is inert but it gets ionized when it reacts with moisture and body fluids. The ionized Ag is highly reactive, as it binds to tissue proteins and brings structural changes in the bacterial cell wall and nuclear membrane leading to cell distortion and death. Ag ions react rapidly with prokaryotic cell walls, whereas the membranes of eukaryotic cells strongly resist the effect of Ag $[7,8]$.

However, some of the recent studies also indicated that $\mathrm{Ag}$ and $\mathrm{Ag}$ compounds show unacceptable toxic effect on human health and the environment. The chronic exposure to Ag causes adverse effects such as permanent bluish-gray discoloration of the skin (argyria) and eyes (argyrosis) [9]. Exposure to soluble Ag compounds may produce other toxic effects such as liver and kidney damage, irritation of the eyes, skin, respiratory and intestinal tract, and changes to blood cells [2]. The normal concentrations of Ag in human tissues are very low. If there is an overexposure, it can be accumulated in mucous membranes, corneas, nails, and spleen [10].

According to Xia et al., Ag nanoparticles (AgNPs) can attach to different tissues and cause potential toxic effects, namely, producing reactive oxygen species and cell activation [11]. It is more toxic to organs and tissues and gradually lead to cell death. Drake and Hazelwood revealed that skin, eyes, brain, liver, kidneys, spleen, and bone marrow are the principle target tissues for Ag deposition following systemic absorption [3]. Sue et al. reported that the overexposure to Ag can cause accumulation of the Ag ions in the skin, blood, liver, spleen, corneas, mucous membranes, kidneys, hair, gingival, and nails [10].

Ag is absorbed into cultured cells by a pinocytic mechanism as in bacteria and fungi which can be interacted with cytoplasmic proteins leading to cell death. According to Arora et al., cultured cells exposed to Ag particles at 6.25-50 $\mu \mathrm{g} / \mathrm{mL}$ showed altered cell shape, evidence of oxidative stress, and increased lipid peroxidation [12].

There has not been any specific investigation done in the lethal effects of Ag on human health such as other heavy metals, hence the present study was aimed to determine the levels of hematological indices (total leukocytes count, red blood count, differential count, hemoglobin [Hb] concentration, hematocrit [HCT], mean corpuscular volume [MCV], mean corpuscular hemoglobin [MCH], mean corpuscular hemoglobin concentration [MCHC], platelet [PLT] count, mean platelet volume [MPV], platelet distribution width [PDW], and red blood cell distribution width [RDW]) among workers exposed to Ag compounds.

\section{MATERIALS AND METHODS}

\section{Studied population}

A cross-sectional study was conducted in the silver jewelry making units located in Coimbatore, Tamil Nadu. A total of 159 silver jewelry unit individuals aged 25-55 years who have residing and working in Coimbatore for many years and have been working in these units were asked to participate in the study in which 148 individuals agreed to do so. These 148 jewelry unit workers were considered as "exposed group" and they were further categorized into 4 groups based on the duration of employment in the unit is given in Table 1. The unexposed group comprised 35 individuals who are living in the same area with 
no relation to making of silver jewelry considered as "control group" (including tailor, repairman, etc.). The demographic and socioeconomic statuses (age, height weight, smoking, and alcoholic habits) were matched between the exposed (B, C, D, and E) and control groups (A).

An in-person survey was carried out for both control and exposed group participants. The study comprised inclusion and exclusion criteria in which workers with minimum 1 year of exposure were included and those with known history of diabetes mellitus, liver diseases, blood transfusion, and any other pathological conditions were excluded from the study. Each study participant received a questionnaire and was orally explained in local language for illiterate, including questions about employment, residences, smoking, and food habits as well as medical history, especially regarding diabetes and liver diseases. Informed consent was obtained from control and exposed group participants, based on their concern they were included for the study.

\section{Sample collection and specimen preparation}

Peripheral venous blood samples were collected from the participants and fresh blood samples were preserved in ice bags during the collection of samples. Whole blood samples were taken for hematological analysis and serum samples were diluted three-fold with double-distilled water before assay of flame atomic absorption spectroscopy (FAAS). Height and weight were measured by standard method. Systolic and diastolic blood pressure was measured using Omron Blood Pressure Monitor: HEM 7112. The blood pressure was expressed in $\mathrm{mmHg}$.

\section{Analytical methods}

Serum Ag concentration was determined by FAAS (SHIMADZU, AA7000) and hematological indices were measured on automated 3-part hematology analyzer, Sysmex KX-21.

\section{Statistical analysis}

SPSS package version 16.0 was used for the statistical analysis of data (SPSS Inc., Chicago, IL, USA). The statistical significant level was set at $p<0.05$. Shapiro-Wilk test was carried out to identify the normal distribution of the data ( $p>0.05)$. ANOVA was performed for normally distributed data and if the data obtained the significant level $(\mathrm{p}<0.05)$, post hoc test was done to know the association or difference between each group. Kruskal-Wallis test was done for non-normally distributed data and further Mann-Whitney U-test was conducted to know the association or difference between the groups.

\section{RESULTS}

Grouping of jewelry industry workers based on duration of their work experience in years are shown in Table 1. According to this each group, hematological indices of jewelry industry workers were compared with control group and significant difference was calculated by appropriate statistical methods. The general profile and sociodemographic characteristic of exposed and control group were listed in Tables 2 and 3 . There were no significant difference in age distribution, smoking and alcoholic habits, height, weight, and blood pressure between the exposed and control group workers.

Smoking habits of the selected participants were expressed in packyears which can be calculated by number of pack years=(number of

Table 1: Grouping of the jewelry industry workers based on duration of their work experience

\begin{tabular}{lllll}
\hline Groups & $\begin{array}{l}\text { Year of } \\
\text { experience }\end{array}$ & $\begin{array}{l}\text { Number of } \\
\text { participants }\end{array}$ & $\begin{array}{l}\text { Frequency of } \\
\text { manufacturing }\end{array}$ \\
\cline { 3 - 5 } & & Frequent & Occasional \\
\hline B & $1-10$ & 32 & 23 & 9 \\
C & $11-20$ & 38 & 33 & 5 \\
D & $21-30$ & 42 & 32 & 10 \\
E & More than 30 & 36 & 27 & 9 \\
\hline
\end{tabular}

cigarettes smoked per day×number of years smoked)/20 (1 pack has 20 cigarettes). Alcohol consumption of selected participants was stated in units/week (1 unit=10 ml).

Ag is considered as a xenobiotic compound for human body and silver jewelry industry workers who had been exposed this compound daily over extended time. Serum Ag concentration was significantly raised $(\mathrm{p}<0.005)$ in exposed groups (, $\mathrm{D}$, and E) than control group (A). Among the exposed groups, concentration of Ag was significantly increased $(p<0.03)$ in group D and E in contrast to group B. Similarly, group E was significantly increased $(\mathrm{p}<0.04)$ than group C (Fig. 1).

\section{Hematology}

Hematological indices were listed in Tables 4 and 5. The hematological profile such as RBC, HCT, and Hb levels of exposure groups (B, C, D, and $E$ ) were found to be significantly decreased $(p<0.05)$ compared to control group (A). Among the exposed groups, C, D, and E groups RBC levels were significantly decreased $(p<0.02)$ compared to group $B$. Similarly, HCT level was significantly decreased in group D $(\mathrm{p}<0.03)$ than the group B. However, other groups did not show any significance difference from each other (Table 4).

$\mathrm{MCH}$ levels were increased significantly $(\mathrm{p}<0.005)$ in exposed groups $\mathrm{C}$, $\mathrm{D}$, and $\mathrm{E}$ than the control group (A). Similarly, among the exposed groups, $\mathrm{MCH}$ levels were increased significantly $(\mathrm{p}<0.03)$ in exposed group $\mathrm{C}$ and D than the group B. MCHC levels were increased significantly $(p<0.001)$ in exposed groups such as B, C, and D when compared to control group (A). Among the exposed groups, MCHC levels were significantly decreased $(\mathrm{p}<0.02)$ in group $\mathrm{E}$ than the groups $\mathrm{B}$ and $\mathrm{C}$. Moreover, there was no significant difference between control and exposed groups of RDW (Table 4).

Table 5 shows the total and differential leukocyte count of workers employed in jewelry industry. Total leukocyte count was observed significantly raising in number $(\mathrm{p}<0.03)$ in exposed groups $(B$ and $D)$ in contrast to control group (A). The other groups did not show any significant difference among and between the groups.

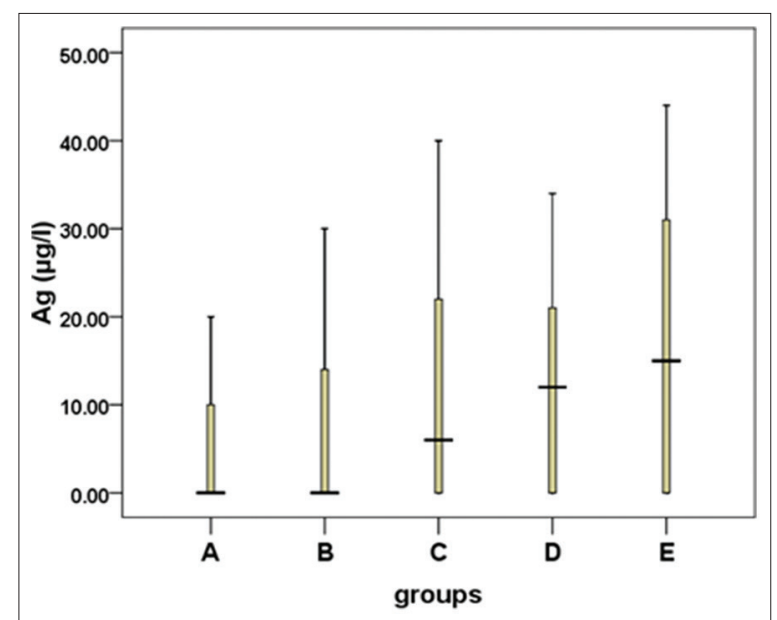

Fig. 1: Serum silver concentration among workers in jewelry industry

Table 2: General profiles of the selected workers employed in jewelry industry

\begin{tabular}{llll}
\hline Groups & Age & Pack-years & Alcoholics \\
\hline Control group $(\mathrm{n}=35)$ & $36 \pm 1.67$ & $0.12 \pm 1.15$ & $9.12 \pm 1.02$ \\
Exposed group $(\mathrm{n}=148)$ & $34 \pm 1.12$ & $0.13 \pm 0.89$ & $9.48 \pm 1.23$ \\
p value & $0.345^{*}$ & $0.654^{*}$ & $0.532^{*}$ \\
\hline
\end{tabular}

*Mean value \pm standard deviation; independent sample t-test computed for groups with unequal sized samples 
Table 3: Sociodemographic characteristics of jewelry industry workers

\begin{tabular}{|c|c|c|c|c|}
\hline \multirow[t]{2}{*}{ Groups } & \multirow[t]{2}{*}{ Height (cm) } & \multirow[t]{2}{*}{ Weight (kg) } & \multicolumn{2}{|c|}{ Blood pressure (mmHg) } \\
\hline & & & Systolic pressure & Diastolic pressure \\
\hline $\begin{array}{l}\text { A. Control }(n=35) \\
\text { Jewelry industry workers (exposed) }\end{array}$ & $156(154-160)$ & $68.42 \pm 9.70$ & $119(120-113)$ & $75.05 \pm 7.75$ \\
\hline B. $1-10$ years of exposure $(n=32)$ & $157(153-161)$ & $67.05 \pm 12.29$ & 119 (117-129) & $78.82 \pm 10.27$ \\
\hline C. $11-20$ years of exposure $(n=38)$ & $156(154-161)$ & $67.25 \pm 14.88$ & $121(112-127)$ & $78.20 \pm 11.06$ \\
\hline D. $21-30$ years of exposure $(n=42)$ & $157(154-160)$ & $65.32 \pm 19.23$ & $120(112-129)$ & $77.97 \pm 6.71$ \\
\hline E. $>30$ years of exposure $(n=36)$ & $154(150-162)$ & $66.33 \pm 13.33$ & $123(115-128)$ & $77.63 \pm 9.24$ \\
\hline $\mathrm{p}$ value $(<0.05)$ & $0.160^{¥}$ & $0.674^{*}$ & $0.223^{¥}$ & $0.350^{*}$ \\
\hline
\end{tabular}

${ }^{¥}$ Median value (interquartile range); Kruskal-Wallis and Mann-Whitney test computed for groups with unequal sized samples; ${ }^{*}$ mean value \pm standard deviation; ANOVA and post-hoc computed for groups with unequal sized samples

Table 4: Hemoglobin, red blood corpuscles, hematocrit, red blood cell distribution width, and red blood cell indices levels in blood among the jewelry industry workers

\begin{tabular}{|c|c|c|c|c|c|c|c|}
\hline \multirow[t]{2}{*}{ Groups } & \multirow{2}{*}{$\begin{array}{l}\text { Hemoglobin } \\
(\mathrm{g} / \mathrm{dl})^{\#}\end{array}$} & \multirow{2}{*}{$\begin{array}{l}\text { Red blood } \\
\text { corpuscles } \\
\left(\times 10^{6} / \mu \mathrm{l}\right)^{*}\end{array}$} & \multirow[t]{2}{*}{ Hematocrit (\%)* } & \multirow{2}{*}{$\begin{array}{l}\text { Red blood cell } \\
\text { distribution } \\
\text { width (fl)* }\end{array}$} & \multicolumn{3}{|c|}{ Red blood cell indices } \\
\hline & & & & & $\begin{array}{l}\text { Mean } \\
\text { corpuscular } \\
\text { volume }(\mathbf{f l})^{*}\end{array}$ & $\begin{array}{l}\text { Mean } \\
\text { corpuscular } \\
\text { hemoglobin }(\mathrm{pg})^{*}\end{array}$ & $\begin{array}{l}\text { Mean } \\
\text { corpuscular } \\
\text { hemoglobin } \\
\text { concentration } \\
(\mathrm{g} / \mathrm{dl})^{*}\end{array}$ \\
\hline $\begin{array}{l}\text { A. Control }(n=43) \\
\text { Jewelry industry } \\
\text { workers }\end{array}$ & $14.6 \pm 1.2$ & $5.0(4.7-5.3)$ & $44(42.3-45)$ & $44.2(41.6-45.5)$ & $88.6(85.1-90.7)$ & $28.9(27.8-30)$ & 32.7 (31.7-33.2) \\
\hline $\begin{array}{l}\text { B. } 1-10 \text { years of } \\
\text { exposure }(n=32)\end{array}$ & $13.7 \pm 1.2$ & $4.9(4.7-5.3)$ & $42.5(39.1-45)$ & $45.1(43.1-48)$ & $86.5(84-90.2)$ & $29(27.1-30.5)$ & $35.35(32.4-36.4)$ \\
\hline $\begin{array}{l}\text { C. } 11-20 \text { years of } \\
\text { exposure }(n=38)\end{array}$ & $13.67 \pm 1.2$ & $4.77(4.6-4.9)$ & $41.2(37.5-43.5)$ & $45(44.3-45.3)$ & $86(84-89.7)$ & 30.35 (29.1-31.2) & $35.35(33.5-36.1)$ \\
\hline $\begin{array}{l}\text { D. } 21-30 \text { years of } \\
\text { exposure }(n=42)\end{array}$ & $13.86 \pm 1.39$ & $4.76(4.3-5.1)$ & $40.95(36.9-43.4)$ & $43.4(42.4-47.9)$ & $87.4(82-93)$ & $29.65(32.3-31.4)$ & $35.50(32.3-36)$ \\
\hline $\begin{array}{l}\text { E. }>30 \text { years of } \\
\text { exposure }(n=36)\end{array}$ & $13.07 \pm 1.22$ & $4.59(4.2-4.9)$ & $40.2(39-44.5)$ & $44.1(43.9-46.8)$ & $90.8(82.5-94.2)$ & $30.1(28.3-31.1)$ & $34.5(34.1-35.6)$ \\
\hline $\mathrm{p}$ value $(<0.05)$ & 0.000 & 0.000 & 0.000 & 0.177 & 0.195 & 0.003 & 0.000 \\
\hline
\end{tabular}

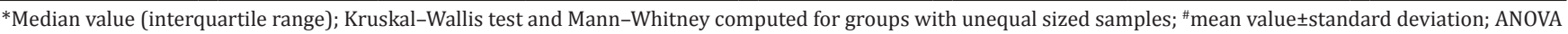
and post-hoc computed for groups with unequal sized samples

Table 5: Levels of total and differential leukocytes, platelets, mean platelet volume, and mean platelet distribution width among the jewelry units workers

\begin{tabular}{|c|c|c|c|c|c|c|c|}
\hline \multirow[t]{2}{*}{ Groups } & \multirow{2}{*}{$\begin{array}{l}\text { Total } \\
\text { leukocytes } \\
\text { count } \\
\left(\times 10^{3} / \mu l\right)^{\#}\end{array}$} & \multicolumn{3}{|c|}{ Differential count } & \multirow{2}{*}{$\begin{array}{l}\text { Platelet } \\
\text { count } \\
\left(\times 10^{3} / \mu \mathrm{l}\right)^{*}\end{array}$} & \multirow{2}{*}{$\begin{array}{l}\text { Mean platelet } \\
\text { volume (fl) }\end{array}$} & \multirow{2}{*}{$\begin{array}{l}\text { Platelet } \\
\text { distribution } \\
\text { width (fl) }\end{array}$} \\
\hline & & $\begin{array}{l}\text { Lymphocytes } \\
\left(\times 10^{3} / \mu \mathrm{l}\right)^{\#}\end{array}$ & $\begin{array}{l}\text { Neutrophils } \\
(\times 103 / \mu \mathrm{l})^{\#}\end{array}$ & $\begin{array}{l}\text { Mixed cells } \\
\left(\times 10^{3} / \mu \mathrm{l}\right)^{\#}\end{array}$ & & & \\
\hline $\begin{array}{l}\text { A. Control }(\mathrm{n}=43) \\
\text { Jewelry industry } \\
\text { workers (exposed) }\end{array}$ & $6.9(5.8-7.5)$ & $2.3(2.1-3.1)$ & $3.7(3.0-4.2)$ & $0.8(0.6-1.0)$ & $232.67 \pm 48.39$ & $9.5(9.2-9.8)$ & $11.5(10.7-12.5)$ \\
\hline B. $1-10$ years of exposure $(n=32)$ & $7.7(6.6-8.2)$ & $3.1(2.8-4.1)$ & $3.4(2.9-3.7)$ & $0.95(0.8-1.0)$ & $241.82 \pm 59.81$ & $9.55(8.5-10.8)$ & $11.9(10.1-14.7)$ \\
\hline D. 21-30 years of exposure $(n=42)$ & $7.0(6.4-7.9)$ & $3.0(1.8-3.9)$ & $3.5(3.2-3.9)$ & $0.9(0.7-1.1)$ & $266.36 \pm 53.30$ & $9.2(9.5-9.1)$ & $10.1(9.8-10.5)$ \\
\hline E. $>30$ years of exposure $(n=36)$ & $6.8(5.5-8.4)$ & $2.6(2.4-2.9)$ & $3.3(2.4-4.7)$ & $0.8(0.7-1.0)$ & $222.00 \pm 46.98$ & $9.2(10.1-9.0)$ & $10.3(9.8-11.2)$ \\
\hline $\mathrm{p}$ value $(<0.05)$ & 0.021 & 0.000 & 0.323 & 0.000 & 0.005 & 0.001 & 0.000 \\
\hline
\end{tabular}

\#Median value (interquartile range); Kruskal-Wallis test and Mann-Whitney computed for groups with unequal sized samples; ${ }^{*}$ mean value \pm standard deviation; ANOVA and post-hoc computed for groups with unequal sized samples

In differential counts such as lymphocytes and mixed cells (including basophils, eosinophils, and monocytes) counts were significantly increased $(p<0.001)$ in exposed groups than the control group. Moreover, lymphocytes count were increased significantly $(\mathrm{p}<0.001)$ in group (B) than group (A). Among the exposed groups, lymphocyte number was significantly raised $(\mathrm{p}<0.001)$ in group $(B)$ when compared to group (E). Similarly, group C lymphocyte count was significantly increased $(\mathrm{p}<0.05)$ than group $\mathrm{E}$.

The number of mixed cells was significantly increased $(p<0.03)$ in exposed groups (B, C, and D) in contrast with control group (A).
Among the exposed groups, group C mixed cell count was significantly increased $(\mathrm{p}<0.01)$ than group B. Furthermore, the number of mixed cells was significantly increased $(p<0.01)$ in group C compared with group $\mathrm{D}$ and $\mathrm{E}$. The number of neutrophils did not show any significant difference between the control and exposed groups.

The PLT count was increased significantly $(\mathrm{p}<0.04)$ in exposed group D in comparison with control group A. Moreover, among the exposed groups, PLT count was significantly increased $(\mathrm{p}<0.004)$ in group D compared to group E. The other groups did not show any significant difference among and between groups. 
PDW and MPV levels were found to be decreased significantly $(\mathrm{p}<0.001)$ in exposed groups (D) than the control group (A). Similarly, among the exposed groups, MPV and PDW levels were significantly decreased $(\mathrm{p}<0.01)$ in group (D) when compared to group B and C. However, the levels of these parameters were increased significantly $(p<0.002)$ in exposed group (E) than the Group (D).

There were no significant difference in serum glucose and total protein levels of exposed and control group participants.

\section{DISCUSSION}

The study reported that Ag concentration was increased in exposed workers than the control group which was supported by an in vivo study, suggested that AgNPs do not induce genotoxicity in bone marrow of male and female rat. Nevertheless, the tissue distribution of AgNPs did show a dose-dependent accumulation of Ag content in all the tissues examined [13]. Ag concentration in lung tissues from Sprague-Dawley rats exposed to AgNPs for 90 days was statistically significant $(\mathrm{p}<0.01)$ and increased with dose. There was also a clear dose-dependent increase in the Ag concentration in the blood [14].

The present study also indicated that there was no significant difference of body mass index between the exposed group and the control group workers. According to Kim et al. 2008, the oral toxicity of AgNPs (60 nm) over 28 days in Sprague-Dawley rats was studied in which male and female rats did not show any significant changes in body weight relative to the doses of AgNPs during the 28 day experiment [13].

Although RBC level was decreased among exposed group workers compared to control group. This study indicated that there were slight decrease in Hb and HCT levels of exposed workers due to the prolonged exposure to Ag which is supported by Cheraghi et al., investigated the effects of AgNPs on hematological parameters in male and female mice, showed that AgNP-treated groups (male, $100 \mathrm{mg} / \mathrm{kg}$ and female, $300 \mathrm{mg} / \mathrm{kg}$ ) RBC count and $\mathrm{Hb}$ were decreased considerably compared to their control group [15].

The red cell indices, namely, MCH and MCHC levels were increased among exposed groups compared to control group, however, it was in the normal range (26-32 pg and 32-36 g/dl, respectively). Although there was no significant difference in MCV levels between the control and exposed groups, the median MCV levels were increased among the exposed groups, might be due to the synthesis of metalloproteins.

Even though the total leukocytes and differential count increased in exposed groups in contrast to control group, among the groups, all these values were decreased in group E than group B, C, and D indicates that producing the resistance or synthesizing metalloprotein against Ag. Bao et al. investigated the effects of chronic cadmium exposure combined with $\gamma$-ray irradiation on the cytotoxicity and genotoxicity of peripheral blood cells and bone marrow cells in rats, revealed that low dose of cadmium $(0.1 \mathrm{mg} \mathrm{CDCl} / \mathrm{kg})$ did not show toxic effects on peripheral blood lymphocytes and white blood cell, moreover it induce metallothionein expression in bone marrow cells [16].

The PLT, PDW, and MPV levels were increased in exposed groups than the control group. The oral toxicity of AgNPs ( $56 \mathrm{~nm}$ ) over 13 weeks (90 days) in rats was studied. After 90 days of exposure, no significant changes were noted in the hematological parameters [13]. The subchronic inhalation toxicity of AgNPs was studied in Sprague-Dawley rats indicated that there were no significant dose-related differences in the hematology values among the groups [14].

The results of the present study were supported by physiological effects of exposure to $\mathrm{Ag}(250 \mu \mathrm{g} \mathrm{Ag} / \mathrm{L}$ or $1000 \mu \mathrm{g} \mathrm{Ag} / \mathrm{L})$ in seawater fishes were investigated using adult starry flounders showed that all fishes survived up to 10 days in $250 \mu \mathrm{g} \mathrm{Ag} / \mathrm{L}$ and started dying after 4 days in $1000 \mu \mathrm{g} \mathrm{Ag} / \mathrm{L}$. Furthermore, there were minimal negative effects on hematological parameters [17]. Likewise, a study of systemic $\mathrm{Ag}$ absorption was done on nanocrystalline Ag dressings of burns in 30 patients by Vlachou et al. reported that there were no changes in hematological values associated with the Ag absorption [18]

\section{CONCLUSION}

The present investigation focused on the hematological indices of the participants exposed to Ag working in silver jewelry manufacturing units. Decrease in RBC indices and increased differential count, MCH, MCHC, PLT, PDW, and MPV levels might be due to exposure to Ag in the jewelry units. From the aforesaid values, it is evident that variations are observed and these variations though appear to be minimal are still deleterious. Future research is warranted with large sample size for future fine tuning and propelling the current study.

\section{REFERENCES}

1. Chen X, Schluesener HJ. Nanosilver: A nanoproduct in medical application. Toxicol Lett 2008;176(1):1-12.

2. Panyala NP, Mendze EM, Havel J. Silver or silver nanoparticles: A hazardous threat to the environment and human health? J Appl Biomed 2008;6(3):117-29.

3. Drake PL, Hazelwood KJ. Exposure-related health effects of silver and silver compounds: A review. Ann Occup Hyg 2005;49(7):575-85.

4. Nomiya K, Yoshizawa A, Tsukagoshi K, Kasuga NC, Hirakawa S, Watanabe J. Synthesis and structural characterization of silver(I), aluminium(III) and cobalt(II) complexes with 4-isopropyltropolone (hinokitiol) showing noteworthy biological activities. Action of silver(I)-oxygen bonding complexes on the antimicrobial activities. J Inorg Biochem 2004;98(1):46-60.

5. Devi JS, Bhimba BV, Ratnam K. In vitro anticancer activity of silver nanoparticles synthesized using the extract of Gelidiella sp. J Pharm Pharm Sci 2012;4(4):710-5.

6. Sivakumar P, Nethradevi C, Renganathan S. Synthesis of silver nanoparticles using Lantana camara fruit extract and its effect on pathogens. Asian J Pharm Clin Res 2012;5(3):97-101

7. Lansdown AB. Silver I: Its antibacterial properties and mechanism of action. J Wound Care 2002;11:125-38.

8. Castellano JJ, Shafii SM, Ko F, Donate G, Wright TE, Mannari RJ, et al. Comparative evaluation of silver-containing antimicrobial dressings and drugs. Int Wound J 2007;4(2):114-22.

9. Gulbranson SH, Hud JA, Hansen RC. Argyria following the use of dietary supplements containing colloidal silver protein. Cutis 2000;66(5):373-4.

10. Sue YM, Lee JY, Wang MC, Lin TK, Sung JM, Huang JJ. Generalized argyria in two chronic hemodialysis patients. Am J Kidney Dis 2001;37(5):1048-51.

11. Xia T, Kovochich M, Brant J, Hotze M, Sempf J, Oberley T, et al. Comparison of the abilities of ambient and manufactured nanoparticles to induce cellular toxicity according to an oxidative stress paradigm. Nano Lett 2006;6(8):1794-807.

12. Arora S, Jain J, Rajwade JM, Paknikar KM. Cellular responses induced by silver nanoparticles: In vitro studies. Toxicol Lett 2008;179(2):93-100.

13. Kim YS, Kim JS, Cho HS, Rha DS, Kim JM, Park JD, et al. Twentyeight-day oral toxicity, genotoxicity, and gender-related tissue distribution of silver nanoparticles in Sprague-Dawley rats. Inhal Toxicol 2008;20(6):575-83.

14. Sung JH, Ji JH, Park JD, Yoon JU, Kim DS, Jeon KS, et al. Subchronic inhalation toxicity of silver nanoparticles. Toxicol Sci 2009;108(2):452-61.

15. Cheraghi J, Hosseini E, Hoshmandfar R, Sahraei R. Hematologic parameters study of male and female rats administrated with different concentrations of silver nanoparticles. Int J Agric Crop Sci 2014;7(10):700-7

16. Bao Y, Chen H, Hu Y, Bai Y, Zhou M, Xu A, et al. Combination effects of chronic cadmium exposure and gamma-irradiation on the genotoxicity and cytotoxicity of peripheral blood lymphocytes and bone marrow cells in rats. Mutat Res 2012;743(1-2):67-74.

17. Hogstrand C, Ferguson EA, Galvez F, Shaw JR, Webb NA, Wood CM. Physiology of acute silver toxicity in the starry flounder (Platichthys stellatus) in seawater. J Comp Physiol B 1999;169(7):461-73.

18. Vlachou E, Chipp E, Shale E, Wilson YT, Papini R, Moiemen NS. The safety of nanocrystalline silver dressings on burns: A study of systemic silver absorption. Burns 2007;33(8):979-85. 